\title{
HUBUNGAN ANTARA STATUS GIZI DAN KEBIASAAN BEROLAHRAGA DENGAN NILAI VOLUME OKSIGEN MAKSIMAL (VO2 MAX) PADA SISWA LAKI - LAKI SMP NEGERI DI TEMANGGUNG SELAMA PANDEMI COVID-19
}

\section{(The Correlation Between The Nutritional Status and Exercise Habits With The Value Of Maximum Oxygen Volume ( $\mathrm{VO}_{2}$ Max) In Male Student At SMP Negeri In Temanggung During The Covid-19 Pandemic)}

\author{
Irvan Dwi Cahyono ${ }^{1}$, Tri Agustina ${ }^{2}$, Sri Wahyu Basuki ${ }^{3}$, Budi Hernawan ${ }^{4}$ \\ ${ }^{1}$ Pendidikan Dokter, Fakultas Kedokteran, Universitas Muhammadiyah Surakarta \\ ${ }^{2,3,4}$ Dosen, Fakultas Kedokteran, Universitas Muhammadiyah Surakarta
}

\author{
*) Correspondence Author \\ dr. Budi Hernawan. M.Sc \\ Fakultas Kedokteran, Universitas Muhammadiyah Surakarta \\ Email: bh235@ums.ac.id
}

\begin{abstract}
The negative impacts of the Covid-19 pandemic include anxiety, stress, reduced appetite, boredom, and physical fitness problems. These conditions certainly affect the nutritional status and also the cardiorespiratory fitness of a person. In Indonesia, at least 15 out of 1000 people, or around 2,784,064 individuals suffer from heart disease. In Central Java Province, $0.61 \%$ of them are children aged 5-14 years old (Riskesdas, 2018). The VO2 Max value is a method for measuring cardio respiration that can be used to determine which children are at risk of suffering from cardiovascular disease. The VO2 Max value is influenced by several factors, including nutritional status and exercise habits. This study aimed to find out the correlation between nutritional status and exercise habits and the value of maximum oxygen volume (VO2 Max) in male students at SMP Negeri in Temanggung during the Covid-19 pandemic. This was a descriptive-analytic study with a cross-sectional design. The sampling was done using the purposive sampling method on 57 samples at SMP Negeri 1 Kaloran. It used Chi-square test for nutritional status variable with $p$ value $=0.000$ and exercise habits with $\mathrm{p}$ value $=0.001$. The logistic regression test was used for each $\mathrm{p}$-value with the nutritional status OR value of 6.640 and the exercise habit OR value of 4.807 and with R Square value of 0.38 or $38 \%$. There was a correlation between nutritional status and exercise habits and the value of maximum oxygen volume (VO2 Max) in male students at SMP Negeri in Temanggung during the Covid-19 pandemic.
\end{abstract}

Keywords: Nutritional status, exercise habits, $\mathrm{VO}_{2} \mathrm{Max}$

\section{Abstrak}

Dampak negatif dari pandemi Covid-19 di antaranya yaitu mengakibatkan kecemasan, stress, penurunan nafsu makan, kebosanan dan juga gangguan kebugaran fisik. Kondisi tersebut tentu berpengaruh terhadap status gizi dan juga kebugaran kardiorespirasi seseorang. Di Indonesia setidaknya, 15 dari 1000 orang, atau sekitar 2.784.064 individu menderita penyakit jantung dan di Provinsi Jawa Tengah sebanyak 0,61\% terjadi pada anak usia 5-14 tahun (Riskesdas, 2018). Nilai $\mathrm{VO}_{2}$ Max adalah metode untuk mengukur kardiorespirasi yang dapat digunakan untuk mengetahui anak yang berisiko terkena penyakit kardiovakuler. Nilai $\mathrm{VO}_{2}$ Max dipengaruhi beberapa faktor di antaranya adalah status gizi dan kebiasaan berolahraga. Mengetahui hubungan antara status gizi dan kebiasaan berolahraga dengan nilai volume oksigen maksimal ( $\mathrm{VO}_{2} \mathrm{Max}$ ) pada siswa laki - laki SMP Negeri di Temanggung selama pandemi Covid-19. Jenis penelitian deskriptif analitik dengan rancangan cross sectional. Pengambilan sampel dilakukan dengan metode purposive sampling sebanyak 57 sampel di SMP Negeri 1 Kaloran. Uji Chi Square variabel status gizi nilai $p=0,000$ dan kebiasaan berolahraga nilai $\mathrm{p}=0,001$. Uji regresi logistik masing-masing nilai p dengan nilai OR status gizi 6,640 dan nilai OR kebiasaan berolahraga 4,807 dan dengan nilai R Square sebesar 0,38 atau 38\%. Terdapat hubungan antara status gizi dan kebiasaan berolahraga dengan nilai volume oksigen maksimal $\left(\mathrm{VO}_{2} \mathrm{Max}\right)$ pada siswa laki - laki SMP Negeri di Temanggung selama pandemi Covid-19.

Kata Kunci : Status Gizi, Kebiasaan Berolahraga, $\mathrm{VO}_{2} \mathrm{Max}$ 


\section{PENDAHULUAN}

Kelompok usia sekolah merupakan kelompok penduduk yang dengan masa pertumbuhan yang cepat dan aktif, serta harus mendapatkan asupan gizi yang memiliki kualitas dan kuantitas nutrisi yang baik. Anak di usia 1214 tahun, kebanyakan masih duduk di bangku sekolah menengah pertama (SMP) dimana pada masa usia tersebut anak-anak banyak melakukan aktivitas fisik atau olahraga, baik olahraga di lingkungan sekolah maupun di luar sekolah, dengan demikian asupan energi yang bergizi sangat dibutuhkan untuk aktifitas. Status gizi pada anak merupakan indikator kecukupan gizi, sehingga sangat penting untuk menilai keadaan pertumbuhan dan status kesehatannya ${ }^{8}$.

Banyak dampak yang ditimbulkan ketika anak mengalami malnutrisi, seperti pada anak dengan status gizi lebih atau obesitas berisiko tinggi terjadinya penyakit degeneratif, seperti hipertensi, diabetes melitus, penyakit kardiovaskuler dan lain-lain.

Hal ini sejalan dengan penelitian yang telah dilakukan oleh Martiningsih \& Haris bahwa adanya korelasi antara kelompok dengan risiko tinggi penyakit kardiovaskuler dengan riwayat obesitas atau over wight dalam 10 tahun terakhir

\section{Penyakit kardiovaskuler menjadi} perhatian dalam masalah kesehatan anak dalam beberapa tahun terakhir. Hal ini disebabkan karena adanya peningkatan munculnya faktor risiko penyakit degeneratif seperti obesitas, hipertensi yang dimulai sejak masa anak-anak dan remaja. Pada anak dengan obesistas memiliki masa lemak tubuh yang berlebih yang dimana kondisi tersebut akan melemahkan fungsi sistem kardirespirasi dan jika tidak dicegah akan berdampak pada penyakit kardiovaskuler.

\section{Data Organisasi Kesehatan Dunia} (WHO, 2020) menyebutkan, lebih dari 17 juta orang di dunia meninggal akibat penyakit jantung dan pembuluh darah. Sedangkan sebagai perbandingan, HIV / AIDS, malaria dan TBC secara keseluruhan membunuh 3 juta populasi dunia.

Berdasarkan data Riset Kesehatan Dasa tahun 2018, angka kejadian penyakit jantung dan pembuluh darah semakin meningkat dari tahun ke tahun. Setidaknya, 15 dari 1000 orang, atau sekitar 2.784.064 individu di Indonesia menderita penyakit jantung dan di Provinsi Jawa Tengah sebanyak $0,61 \%$ terjadi pada anak usia 5-14 tahun $^{12}$ 
Volume oksigen maksimum atau $\mathrm{VO}_{2}$

Max adalah metode untuk mengukur kardiorespirasi yang dapat digunakan untuk mengetahui anak yang berisiko terkena penyakit kardiovakuler Anak dengan $\mathrm{VO}_{2}$ Max yang tinggi memiliki risiko yang lebih rendah terhadap penyakit kardiovaskuler dan sindrom metabolik ${ }^{5}$.

Volume oksigen maksimal atau $\mathrm{VO}_{2}$ Max adalah indikator yang penting untuk mengetahui kapasitas kardiorespirasi seseorang, tingginya nilai $\mathrm{VO}_{2}$ Max dapat menurunkan faktor risiko penyakit kardiovaskuler ${ }^{3}$. Salah satu faktor yang mempengaruhi $\mathrm{VO}_{2} \mathrm{Max}$ adalah aktivitas fisik atau kebiasaan olahraga.

Di Indonesia dengan ditetapkannya pandemi Covid-19 membuat semua aktivitas menjadi dibatasi. Pemerintah Indonesia menerapkan kebijakan seperti social distancing maupun physical distancing dan juga melakaukan pekerjaan dari rumah, hal ini dilakukan untuk memutus mata rantai penyebaran virus Covid-19.

Dampak negatif yang ditimbulkan dari kebiasaan baru tersebut diantranya yaitu mengakibatkan kecemasan, stress, penurunan nafsu makan, kebosanan dan juga gangguan kebugaran fisik. Kondisi-kondisi tersebut tentu berpengaruh terhadap ststus gizi dan juga

kebugaran kardiorespirasi seseorang.

\section{METODE}

Jenis penelitian ini merupakan penelitian deskriptif analitik dengan menggunakan metode cross sectional. Penelitian ini dilaksanakan di SMP Negeri 1 Kaloran Kabupaten Temanggung. Waktu pelaksanaan pada bulan Desember 2020. Besar sampel yang digunakan masing-masing 57 sampel menggunakan tehnik pengambilan purposive sampling. Pengambilan data status gizi menggunakan parameter IMT menurut umur, data kebiasaan berolahraga menggunakan kuesioner kebiasaan berolahraga dan data $\mathrm{VO}_{2}$ Max menggunakan metode Multistage Fitness Test (MFT). Selanjutnya data dianalisis dengan menggunakan uji chi-square dan uji regresi logistik. . Penelitian ini juga telah mendapat persetujuan oleh Komisi Etik Penelitian Kesehatan (KEPK) FK UMS dengan nomor 3220/B.1/KEPK-FKUMS/I/2021.

\section{HASIL}

Penelitian ini dilakukan di SMP Negeri 1 Kaloran pada bulan Desember 2020 - Januari 2021. Responden yang ikut dan memenuhi kriteria inklusi dalam penelitian ini berjumlah 57 siswa dengan teknik purposive sampling.

Tabel 1. Karakteristik Responden 


\begin{tabular}{cc}
\hline Variabel & Jumlah \\
\hline Status Gizi & 35 \\
Tidak normal & 22 \\
Normal & \\
Kebiasaan Berolahraga & 33 \\
Jarang & 24 \\
Sering & \\
Buruk & 43 \\
Baik & 14 \\
\hline
\end{tabular}

Sumber : Data SPSS yang diolah, 2021

Data pada Tabel 1. . Menunjukkan juga responden yang jarang berolahraga dengan responden yang memiliki status gizi tidak nilai $\mathrm{VO}_{2}$ Max buruk lebih banyak daripada normal dan memiliki nilai $\mathrm{VO}_{2}$ Max buruk lebih responden yang sering berolahraga dengan nilai banyak daripada responden dengan status gizi $\mathrm{VO}_{2}$ Max baik. normal dan memiliki nilai $\mathrm{VO}_{2} \mathrm{Max}$ baik, dan

Tabel 2. Hasil Analisis Bivariat Status Gizi dengan Nilai VO2 Max

\begin{tabular}{cccccccc}
\hline \multirow{2}{*}{$\begin{array}{c}\text { Variabel } \\
\end{array}$} & Buruk & $\%$ & Baik & $\%$ & Total & $p$-value & Keterangan \\
\hline Status Gizi & & & & & & \\
Tidak Normal & 32 & $91,4 \%$ & 3 & $8,6 \%$ & 35 & & Ada \\
Normal & 11 & $50 \%$ & 11 & $50 \%$ & 22 & & Hubungan \\
Total & $\mathbf{4 3}$ & $\mathbf{7 5 , 4 \%}$ & $\mathbf{1 4}$ & $\mathbf{2 4 , 6 \%}$ & $\mathbf{5 7}$ & & \\
\hline
\end{tabular}

Sumber : Data SPSS yang diolah, 2021

Berdasarkan Tabel 2. Diketahui dari 57 responden, terdapat 43 responden $(75,4 \%)$ dengan nilai $\mathrm{VO}_{2}$ Max buruk. Dari 43 responden tersebut, terdapat sebanyak 32 responden $(91,4 \%)$ mempunyai status gizi tidak normal dan sebanyak 11 responden (50\%) mempunyai status gizi normal. Responden dengan nilai $\mathrm{VO}_{2} \mathrm{Max}$ baik sebanyak 14 responden (24,6\%). Dari 14 responden tersebut, sebanyak 3 responden $(8,6 \%)$ mempunyai status gizi tidak normal dan 
sebanyak 11 responden (50\%) mempunyai status gizi normal. value $=<0,05$ yang artinya status gizi dan nilai $\mathrm{VO}_{2}$ Max memiliki hubungan yang signifikan.

Berdasarkan hasil analisis statistik $C h i$

Square menunjukkan nilai probabillity ( $p$ -

Tabel 3. Hasil Analisis Bivariat Kebiasaan Berolahraga dengan Nilai VO2 Max

\begin{tabular}{cccccccc}
\hline \multirow{2}{*}{$\begin{array}{c}\text { Variabel } \\
\end{array}$} & Buruk & $\%$ & Baik & $\%$ & Total & $p$-value & Keterangan \\
& & & & & & & \\
Kebiasaan Berolahraga & 30 & $90,9 \%$ & 3 & $9,1 \%$ & 33 & & Ada \\
Jarang & 13 & $\mathbf{5 4 , 2 \%}$ & 11 & $45,8 \%$ & 24 & & Hubungan \\
Sering & $\mathbf{4 3}$ & $\mathbf{7 5 , 4 \%}$ & $\mathbf{1 4}$ & $\mathbf{2 4 , 6 \%}$ & $\mathbf{5 7}$ & & \\
\hline
\end{tabular}

Sumber : Data SPSS yang diolah, 2021

Tabel 3. Diketahui dari 57 responden, responden $(9,1 \%)$ yang jarang berolahraga dan terdapat 43 responden $(75,4 \%)$ dengan nilai $\mathrm{VO}_{2}$ sebanyak 11 responden $(45,8 \%)$ yang sering Max buruk. Dari 43 responden tersebut, terdapat berolahraga.

sebanyak 30 responden $(90,9 \%)$ yang jarang berolahraga dan sebanyak 13 responden $(54,2 \%)$ yang sering berolahraga. Responden dengan nilai $\mathrm{VO}_{2}$ Max baik sebanyak 14 responden (24,6\%). Dari 14 responden tersebut, sebanyak 3

Berdasarkan hasil analisis statistik $C h i$ Square menunjukkan nilai probabillity ( $p$ value $)=<0,05$ yang artinya status gizi dan nilai $\mathrm{VO}_{2}$ Max memiliki hubungan yang signifikan.

Tabel 4. Hasil Analisis Multivariat Kebiasaan Berolahraga dengan Nilai VO2 Max

\begin{tabular}{|c|c|c|c|c|c|}
\hline \multirow{3}{*}{ Variabel } & \multirow{3}{*}{ B } & \multicolumn{4}{|c|}{ IK $95 \%$} \\
\hline & & \multirow[t]{2}{*}{$O R(\exp . B)$} & & & \multirow[t]{2}{*}{$p$-value } \\
\hline & & & Min & $\max$ & \\
\hline Status Gizi & 1,893 & 6,640 & 1,433 & 30,772 & 0,016 \\
\hline \multicolumn{6}{|l|}{ Kebiasaan } \\
\hline & 1,570 & 4,807 & 1,023 & 22,597 & 0,047 \\
\hline \multicolumn{6}{|l|}{ Berolahraga } \\
\hline Constant & $-2,989$ &, 050 & & & 0,000 \\
\hline
\end{tabular}

Sumber : Data SPSS yang diolah, 2021 
Berdasarkan tabel 4. Dari hasil analisis multivariat didapatkan hasil nilai $\mathrm{p}=0,016$ $(<0.05)$ antara status gizi dengan nilai $\mathrm{VO}_{2} \mathrm{Max}$ dan nilai $\mathrm{p}=0,047$ antara kebiasaan berolahraga dengan nilai $\mathrm{VO}_{2}$ Max. Pada rentang interval kepercayaan (IK) dari OR tiap variabel tidak melewati angka 1 yang berarti varaiabel status gizi dan kebiasaan berolahraga memiliki hubungan yang bermakna dengan nlai $\mathrm{VO}_{2}$ Max.

Nilai OR status gizi adalah 6,640 yang berarti kelompok yang memiliki status gizi tidak normal memiliki resiko 6,640 kali lebih besar mendapatkan hasil $\mathrm{VO}_{2}$ Max yang buruk dibandingkan dengan yang memiliki status gizi normal.

Nilai OR kebiasaan berolahraga adalah 4,807 yang berarti kelompok yang jarang berolahraga memiliki resiko 4,807 mendapatkan hasil $\mathrm{VO}_{2} \mathrm{Max}$ yang buruk dibandingkan dengan yang sering berolahraga.

Nilai Nagelkerke $R$ Square sebesar 0,380 menunjukkan bahwa kemampuan variabel independen dalam menjelaskan variabel dependen adalah 0,380 atau 38\% dan terdapat $100 \%-38 \%=62 \%$ faktor lain diluar penelitian yang menjelaskan variabel dependen.

\section{PEMBAHASAN}

Berdasarkan hasil penelitian dapat diketahui bahwa dari 57 responden, lebih banyak siswa yang memiliki nilai $\mathrm{VO}_{2}$ Max buruk yaitu sebanyak 43 siswa $(75,4 \%)$ dibandingkan dengan siswa yang memiliki nilai $\mathrm{VO}_{2}$ Max baik yaitu sebanyak 14 siswa $(24,6 \%)$.

Hasil penelitian antara status gizi dengan nilai $\mathrm{VO}_{2}$ Max menunjukkan mayoritas responden memiliki status gizi yang tidak normal dan memiliki nilai $\mathrm{VO}_{2} \mathrm{Max}$ yang buruk. Setelah dilakukan uji Chi Square diperoleh hasil $\mathrm{p}=0.000(\mathrm{p}<0,05)$ maka hipotesis dapat diterima yakni terdapat hubungan yang signifikan antara status gizi dengan nilai $\mathrm{VO}_{2} \mathrm{Max}$ pada siswa lakilaki SMP Negeri 1 Kaloran.

Hasil penelitian ini didukung oleh penelitian (Andriani, 2016) yang menjelaskan bahwa terdapat hubungan yang signifikan antara status gizi dengan nilai $\mathrm{VO}_{2} \operatorname{Max}(\mathrm{p}=0,016)$ dan penelitian (Salam, 2020) ada hubungan yang bermakna antara status gizi dengan nilai $\mathrm{VO}_{2}$ Max pada atlet PERBASI Pangkep $(\mathrm{p}=0,00)$. Hasil yang sama juga didapatkan pada penelitian yang dilakukan oleh (Eviana, 2016) yang menyatakan bahwa hubungan yang bermakna antara status gizi berdasarkan IMT/U dengan $V_{2} \operatorname{Max}(\mathrm{p}=0,002)$ dimana anak dengan status gizi tidak normal berisiko 5,3 kali untuk memiliki $\mathrm{VO}_{2} \mathrm{Max}$ rendah. Rendahnya nilai $\mathrm{VO}_{2}$ Max pada anak dengan status gizi lebih atau obesitas disebabkan karena peningkatan kinerja 
tubuh untuk menggerakkan beban tubuhnya yang berlebih. Hal tersebut juga sejalan dengan penelitian yang dilakukan oleh (Hung, et al., 2014) bahwa obesitas menjadi faktor resiko rendahnya nilai $\mathrm{VO}_{2} \mathrm{Max}^{7}$.

$$
\text { Penelitian Asmilyadi }
$$

menjelaskan bahwa pada anak dengan status gizi kurang, rendahnya nilai $\mathrm{VO}_{2}$ Max disebabkan karena tidak adanya energi yang disediakan oleh tubuh untuk melakukan gerak, terlebih jenis olahraga yang dipilih adalah olahraga yang berat yang sangat membutuhkan asupan gizi yang cukup. Sel-sel otak membutuhkan makanan yang cukup untuk melakukan kerja. Jika makan untuk sel-sel tersebut tersedia dengan baik ditubuh maka kerja sel otak akan berjalan dengan lancar. Sebaliknya jika tidak ada pasokan makan untuk sel melakukan kerja maka otak akan sulit untuk berkonsentrasi dengan malakukan kerja secara maksimal.

Hasil penelitian antara status gizi dengan nilai $\mathrm{VO}_{2}$ Max terdapat 3 responden $(8,6 \%)$ dengan status gizi tidak normal tetapi memiliki nilai $\mathrm{VO}_{2}$ Max yang baik. Hal ini disebabkan karena faktor lain seperti adanya data-data tes khusus, seperti intensitas, durasi, efisiensi mekanisme didalam melakukan tes, dan motivasi. Pada penelitian ini juga terdapat 11 responden (50\%) dengan status gizi normal tetapi memiliki nilai $\mathrm{VO}_{2}$ Max yang buruk. Hal ini dapat disebabkan oleh beberapa faktor salah satunya adalah riwayat penyakit, riwayat penyakit yang pernah diderita berpengaruh dengan nilai $\mathrm{VO}_{2}$ Max. Besarnya ambilan oksigen maksimal $\left(\mathrm{VO}_{2} \quad \mathrm{Max}\right)$ seseorang ditentukan oleh sistem kardiovaskuler dan sistem respirasi. Apabila terdapat penyakit yang berkaitan dengan sistem kardivaskuler maupun respirasi, maka dapat menurunkan besaran ambilan oksigen maksimum atau $\mathrm{VO}_{2}$ Max yang diperoleh $^{5}$.

Hasil penelitian anara kebiasaan berolahraga dengan nilai $\mathrm{VO}_{2} \mathrm{Max}$ menunjukkan mayoritas responden jarang berolahraga dan memiliki nilai $\mathrm{VO}_{2}$ Max yang buruk. Dari hasil penelitian tersebut dilakukan uji statistik $C h i$ Square diperoleh hasil $\mathrm{p}=0,001$, maka hipotesis dapat diterima yaitu terdapat hubungan antara kebiasaan berolahraga dengan nilai $\mathrm{VO}_{2}$ Max pada siswa laki-laki SMP Negeri 1 Kaloran.

Hasil penelitian ini sesuai dengan penelitian $^{1}$ mengenai hubungan kebiasaan berolahraga dengan nilai $\mathrm{VO}_{2} \mathrm{Max}$ pada remaja siswa kelas XI SMK Negeri 11 Semarang. Penelitian tersebut dilakukan dengan pendekatan cross sectional dan analisis data menggunakan Chi Square di dapatkan hasil bahwa terdapat hubungan yang bermakna antara kebiasaan 
berolahraga dengan nilai $\mathrm{VO}_{2} \mathrm{Max}$ dengan nilai $\mathrm{p}=0,000$. Sejalan juga dengan penelitian Hanifah (2015) yang menunjukkan ada hubungan yang signifikan dimana kebiasaan olahraga mempengaruhi hasil nilai $\mathrm{VO}_{2} \mathrm{Max}$ siswa SMA Negeri 1 Balung Kabupaten Jember. Hasil yang sama juga didapatkan pada penelitian $^{14}$ menyimpulkan bahwa ada hubungan yang bermakna antara kebiasaan olahraga dengan $\mathrm{VO}_{2}$ Max pada Mahasiswa berolahraga di UNIKA Atma Jaya dengan nilai $\mathrm{p}=0,003$, kebiasaan olahraga dengan tingkat sedang memiliki hubungan yang bermakna dibandingkan dengan tingkat kebiasaan olahraga lainnya. Salah satu yang menyebabkan hal ini terjadi adalah intensitas olahraga yang dilakukan.

Peningkatan $\mathrm{VO}_{2} \quad$ Max disebabkan karena intensits olahraga yang mengakibatkan jantung dan paru beradaptasi terhadap aktivitas olahraga. Pada sistem kardiovaskular terjadi peningkatan curah jantung yang bertujuan untuk mempertahankan otot-otot rangka yang sedang bekerja sehingga terjadi peningkatan aliran darah untuk memenuhi kebutuhan oksigen

Selama melakukan aktivitas fisik, sistem respirasi bekerja lebih banyak karena konsumsi oksigen, ventilasi pulmonal dan alveolar serta kapasitas difusi oksigen meningkat untuk memenuhi kebutuhan oksigen yang tinggi terutama pada otot rangka. Karena kebutuhan oksigen yang diperlukan pada otot selama melakukan aktifitas fisik meningkat, maka sistem kardiovaskuler pun harus meningkatkan tekanan darah, volume sekuncup (stroke volume), denyut jantung (heart rate), dan cardiac output untuk memenuhi kebutuhan oksigen yang diperlukan oleh jaringan otot. Agar hal tersebut terpenuhi, maka pada saat yang sama, tubuh mengurangi aliran darah ke organorgan yang tidak terlalu aktif selama melakukan latihan fisik, seperti ginjal, hati dan organ-organ pada saluran pencernaan. Latihan fisik yang dilakukan secara teratur akan membuat sistem kardiovaskuler lebih efisien dalam hal memompa darah dan mengantarkan oksigen ke otot-otot yang dipergunakan saat berolahraga ${ }^{9}$.

Hasil penelitian antara kebiasaan berolahraga dengan nilai $\mathrm{VO}_{2}$ Max terdapat 3 responden $(9,1 \%)$ yang jarang berolahraga tetapi memiliki nilai $\mathrm{VO}_{2} \mathrm{Max}$ yang baik. Hal ini dapat disebabkan karena faktor lain seperti seperti postur tubuh dan massa otot yang digunakan. Postur tubuh harus tegak pada saat dilakukan tes, karena dengan posisi berdiri nilai konsumsi oksigen maksimal akan dicapai. Pencapaian konsusmi oksigen maksimal juga dapat dicapai dengan melibatkan otot-otot besar ${ }^{2}$. 
Pada penelitian ini juga terdapat 13 responden $(54,2 \%)$ yang sering berolahraga tetapi memiliki nilai $\mathrm{VO}_{2}$ Max yang buruk. Hal ini dapat disebabkan oleh beberapa faktor salah satunya adalah bed-rest dalam waktu yang lama dapat menurunkan nilai $\mathrm{VO}_{2} \mathrm{Max}$ antara $15 \%$ $25 \%$, berkebalikan dengan latihan fisik yang dilakukan terus-menerus secara teratur dapat meningkatkan $\mathrm{VO}_{2}$ Max dengan nilai yang hampir serupa ${ }^{11}$.

Hasil analisis multivariat didapatkan hasil nilai $\mathrm{p}=0,016(<0.05)$ antara status gizi dengan nilai $\mathrm{VO}_{2}$ Max dan nilai $\mathrm{p}=0,047$ antara kebiasaan berolahraga dengan nilai $\mathrm{VO}_{2}$ Max. Pada rentang interval kepercayaan (IK) dari OR tiap variabel tidak melewati angka 1 yang berarti varaiabel status gizi dan kebiasaan berolahraga memiliki hubungan yang bermakna dengan nlai $\mathrm{VO}_{2}$ Max.

Nilai OR status gizi adalah 6,640 yang berarti kelompok yang memiliki status gizi tidak normal memiliki resiko 6,640 kali lebih besar mendapatkan hasil $\mathrm{VO}_{2}$ Max yang buruk dibandingkan dengan yang memiliki status gizi normal.

Nilai OR kebiasaan berolahraga adalah 4,807 yang berarti kelompok yang jarang berolahraga memiliki resiko 4,807 mendapatkan hasil $\mathrm{VO}_{2}$ Max yang buruk dibandingkan dengan yang sering berolahraga.

Nilai Nagelkerke $R$ Square sebesar 0,380 menunjukkan bahwa kemampuan variabel independen dalam menjelaskan variabel dependen adalah 0,380 atau $38 \%$ dan terdapat $100 \%-38 \%=62 \%$ faktor lain diluar penelitian yang menjelaskan variabel dependen.

\section{KESIMPULAN DAN SARAN}

Kesimpulan akhir setelah analisis multivatiat didapatkan hasil berikut :

Ada hubungan antara status gizi dan kebiasaan berolahraga terhadap nilai volume oksigen maksimal ( $\mathrm{VO}_{2}$ Max) pada anak SMP Negeri di Temanggung selama pandemi Covid-19.

Berdasarkan hasil penelitian ini dapat disampaikan bebrapa saran sebagai berikut :

1. Untuk para siswa SMP Negeri 1 Kaloran sebaiknya bisa lebih memperhatikan asupan gizi untuk tubuhnya, sehingga diharapkan mampu memperoleh ststus gizi yang baik.

2. Untuk meningkatkan nilai $\mathrm{VO}_{2}$ Max para siswa SMP Negeri 1 Kaloran, sebaiknya melakukan aktivtas fisik berupa olahraga aerobik seperti lari, bersepeda atau berenang. Dengan frekuensi 3 kali dalam 1 minggu dan dengan durasi lama latihan 3060 menit/olahraga. 
3. Untuk menjaga dan meningkatkan nilai $\mathrm{VO}_{2}$ Max para siswa SMP Negeri 1 Kaloran, sebaiknya dilakukan pengukuran nilai $\mathrm{VO}_{2}$ Max sebanyak 1 kali setiap bulan sebagai evaluasi terhadap program latihan yang telah diberikan.

\section{DAFTAR PUSTAKA}

1. Alamsyah, D. A. N., Hestiningsih, R. \& Saraswati, L. D., 2017. Faktor-Faktor Yang Berhubungan Dengan Kebugaran Jasmani Pada Remaja Siswa Kelas XI SMK Negeri 11 Semarang. Jurnal Kesehatan Masyarakat, 5(3), pp. 77-86.

2. Albertus Fenanlampir, M. A. \& Faruq, D. M. M., 2015. Tes dan Pengukuran dalam Olahraga. Yogyakarta: CV ANDI OFFSET.

3. Andriani, R., 2016. Hubungan Antara Indeks Massa Tubuh Dan Aktivitas Fisik Dengan Volume Oksigen Maksimum, s.1.: Universitas Muhammadiyah Surakarta.

4. Asmilyadi, R. \& Yendrizal, 2020. Hubungan Antara Kemampuan Vo2max Dan Status Gizi Dengan Hasil Belajar Penjasorkes Siswa Di SMA Negeri 2 Kerinci. Jurnal Patriot, 2(2), pp. 537-548.

5. Eviana, R., 2016. Hubungan Status Gizi Dengan Vo2max Anak Sekolah Dasar, Semarang: Studi Ilmu Gizi Fakultas Kedokteran Universitas Diponegoro..

6. Hanifah, S., 2015. Analisis Tingkat Vo2Max Siswa SMA Negeri 1 Balung Kabupaten Jember. e-journal Kesehatan Olahraga FIK UNESA, 03(01), pp. 276-286.

7. Hung, T.-H., Liao, P.-A., Chang, H.-H., Wang, J.-H., Wu, M.-C., 2014. Examining the Relationship between Cardiorespiratory Fitness and Body Weight Status: Empirical
Evidence from a Population-Based Survey of Adults in Taiwan. The Scientific World Journal, Volume 2014, pp. 1-7.

8. Indriakasia, S., 2015. Gambaran Status Gizi Dan Asupan Lemak Anak Usia 13-15 Tahun Di Ciputat. Jakarta: UIN Syarif Hidayatullah.

9. Ismanto, Sulaeman, A. \& Riyadi, H., 2014. Hubungan Status Gizi, Status Kesehatan Dan Aktivitas Fisik Dengan Kebugaran Jasmani Atlet Bulutangkis Jaya Raya Jakarta. Ekologia, 12(01), pp. 26-37.

10. Martiningsih \& Haris, A., 2019. Risiko Penyakit Kardiovaskuler Pada Peserta Program Pengelolaan Penyakit Kronis (Prolanis) Di Puskesmas Kota Bima: Korelasinya Dengan Ankle Brachial Index Dan Obesitas. Jurnal Keperawatan Indonesia, 22(3), pp. 200-208.

11. Nosa, A. S., 2013. Survei Tingkat Kebugaran Jasmani Pada Pemain Persatuan Sepakbola Indonesia Lumajang. Jurnal Prestasi Olahraga, 1(1), pp. 1-8.

12. Riskesdas, 2018. Laporan Provinsi Jawa Tengah Riskesdas 2018. Jakarta: Lembaga Penerbit Badan Penelitian dan Pengembangan Kesehatan (LPB).

13. Salam, N. A., 2020. Hubungan Status Gizi dan Hidrasi terhadap VO2max pada Atlet Perbasi Pangkep, Makassar: Program Studi Ilmu Keolahragaan Fakultas Ilmu Keolahragaan Universitas Negeri Makassar.

14. Setiawan, C. V., Ridjab, D. A. \& Prastowo, N. A., 2020. Pengaruh Kebiasaan Olahraga Terhadap Laju Jantung Dan Vo2max Pada Mahasiswa Di UNIKA Atma Jaya Jakarta, Jakarta: Unika Atma Jaya.

15. WHO, 2020. World Health Organization Cardiovascular diseases (CVDs). [Online] Available at: https://www.who.int/healthtopics/cardiovascular-diseases/\#tab=tab_1 [Accessed 07 Desember 2020]. 